ment in 1957-58. Aeronautical engineering he regards as possessing high claims, but these must be considered with the claims of other chairs when more is known as to the financial resources available from the University Grants Committee. When the conversion of the cotton mill is complete, it is hoped to build a block of lecture rooms and a new department of civil engineering, thus permitting a redistribution of space which will allow expansion of all depart. ments. $\mathrm{He}$ suggests that a second vice-principal should be appointed to take charge of the Department of Industrial Co-operation, and looks to a Department of Polymer Chemistry to supplement the work done in the Textile Department as a whole, as well as to the rapid development of the Department of Industrial Administration and of a school of research in printing, particularly in association with photography.

\title{
OBITUARY
}

\section{Prof. Frederick G. Donnan, C.B.E., F.R.S.}

ON a September day almost thirty years ago, a young man stood in front of the apple-green door of No. 23 Woburn Square in London, calling for the first time on the famous scientist to whose laboratory he had been attracted from five thousand miles away. The interview went on for some time while Prof. F. G. Donnan patiently persuaded the young man to give up the narrow field of physical chemistry that he had planned and to choose one which was broader and was expanding rapidly. But the young man's eagerness to start that afternoon was squashed by : "I don't think you should come into the laboratory for a week. First, get to know London past and present, visit its museums and art galleries, its theatres-just walk about and then tell me what you've learned-this time next week".

So began one person's story of Donnan which was to end a few weeks ago in Canterbury Hospital, where old age had taken him. Then, as always, his interest was in the London he loved, in the affairs and doings of the many people who could claim to be his friends. He died on December 16.

In September 1927 Donnan was fifty-seven years old. The high days of his own personal scientific achievements were past. The best-known one, his treatment of ionic equilibria across semi-permeable membranes, had long since become a foundation stone of modern physiology. The flood of honours was, however, in full swing. Details of these will no doubt appear elsewhere and will show the esteem in which his work was held, not only by his colleagues in the Royal Society-he was awarded the Davy Medal in 1928-but also by universities and scientific societies all over the world. For Donnan was one of the great men of physical chemistry in that era when this branch struggled to achieve its place alongside the two giants, inorganic and organic chemistry. Later, he helped this new branch to become the basic or unifying theme of all the chemistries, including biochemistry, that it is to-day. His work spanned the field of physical chemistry from chemical thermodynamics to colloids, making the former more useful and the latter more 'scientific'.

In 1927, the school of physical chemistry at University College was at its height. But it was not a school of the type where much of the activity is devoted to the development of the ideas of an agile and able man at the top. It was certainly bound around one man, or rather around a personality whose "greatest joy in life has always been the making and helping of young scientific men", to quote his own words. It was a school of many parts with scarcely a side of physical chemistry unrepre- sented. In the work and personal activities of all the eighty-ninety staff, fellows and research students, Donnan took an interest. He would with patience listen to the embryonic ideas of the inexperienced, and through questions gently explore a weakness or give a lead to fresh ideas. Somehow or other he skilfully avoided filling in the missing ideas himself but stimulated them in others. His name appears in the acknowledgments of hundreds of scientific papers, but in this period rarely as an author.

One of the outstanding characteristics of the school was its international character; research students came in continuous streams from every part of the world. This was partly because of the high esteem in which Donnan's work was held, but more because of the friendly relations he established abroad. He travelled extensively, and everywhere he was received in a princely manner and with affection. He was an international man, as his foreign secretaryship of the Chemical Society indicated. His extended help to the victims of Hitler is a measure of his interests and his sympathy.

No. 23 Woburn Square played a major part in every Donnan story. To it came people from all over the world for discussion not so much of science as of philosophy and 'many things'. To meet them were invited the young men and women of the College. For Donnan knew everybody that mattered in science and especially in industry, and he made it a pleasant duty to ensure that his students benefited by this. A studentship with Donnan was a passport to travels abroad. The path to a career in great firms like Imperial Chemical Industries was well signposted by him. In the reverse direction he persuaded industrialists to take an interest in universities and help them financially.

'The hospitality in that home had an elegance and a quality that one imagined belonged to a bygone age. But its success was largely due to two sistersNora, who ran the house (she died in May 1956), and Jane, who organized things at his office and his home, and who predeceased him by only three days.

When Donnan retired in 1937 , he progressively cut himself off from the whirl of the London scientific circle. Soon after the bombing of London started, the family moved to the charming Kentish village of Hartlip just off the Chatham-Sittingbourne road, where with his strong physique to help him, Donnan almost took on the new role of a country squire. A bomb destroyed the house in Woburn Square a week after the move.

His retirement was complete. Except to fulfil some of his continuing commitments such as for the Society for Visiting Scientists, and to attend special occasions such as the jubilee of the Faraday Society, 
of which he was a founder member, he rarely came up to London. A very special occasion was the dinner given to him at University College by many of his old students on his eightieth birthday. Hundreds of his friends have kept in touch with him by letter or visits through the whole of his retirement.

Much remains to be said about this great man of science. An attractive and inspiring personality he certainly had. He was generous to a fault; his testimonials had to be heavily discounted. It was surprising to many that, while he could inspire selfconfidence in others, he could not do the same for himself-perhaps the two are connected, for his sympathy and his generosity in praise might have sprung from a knowledge of what is needed by others. Religious ?-certainly in the de facto sense but not de jure. A sense of humour-who will forget his speech at a student rag dinner when a famous French professor was given his 'presidential' chain of office which incorporated a chain commonly found (only) in English households. As a teacher even the second law of thermodynamics took on a new light. In short, a man that many would like to be able to emulate.

The bomb that fell in Woburn Square left standing only the apple-green door. There it stood for many years until it was demolished some months ago to make room for a new extension to the University of London. Perhaps it will be replaced by a blue plaque, "Donnan lived here". C. F. Goodeve

\section{NEWS and VIEWS}

\section{Prof. S. Chandrasekhar}

THE award of the Rumford Premium of the American Academy of Arts and Sciences to Prof. Subrahmanyan Chandrasekhar for his researches on radiative transfer of energy in the interior of stars was recently reported in Nature (179, 77 ; 1957). This further recognition of the valuable work of one who has already received the Gold Medal of the Royal Astronomical Society and the Bruce Medal of the Astronomical Society of the Pacific will be welcomed by Prof. Chandrasekhar's many friends on the east side of the Atlantic. Proceeding to Cambridge in 1930 after graduating at the Presidency College, Madras, he was awarded his $\mathrm{Ph.D}$. in theoretical physics, was elected to a fellowship at Trinity College, and later obtained the degree of Sc.D. in theoretical astrophysics. In 1936 Prof. Chandrasekhar went to the Yerkes Observatory; there and in the University of Chicago he has gathered around him an influential group attacking a wide field of research in theoretical astrophysics. The Rumford award refers to one side of his work, but the titles of his other books, "An Introduction to the Study of Stellar Structure" and "Principles of Stellar Dynamics", cover different fields in which he has developed important studies; his George Darwin Lecture on "Problems of Stability in Hydrodynamics and Hydromagnetics" shows how widely Prof. Chandrasekhar casts his net. In his mathematical work he has made many fundamental contributions to astrophysics.

\section{Physiology at Middlesex Hospital Medical School : Prof. Eric Neil}

Prof. Eric NeIL, who has just been appointed to the John Astor chair of physiology at the Middlesex Hospital Medical School in succession to the late Prof. Samson Wright, was a student at the School of Medicine in Leeds, where he graduated in 1942. He obtained his M.D. in 1944 and was awarded his D.Sc. in 1953. During 1942-50 he was first demonstrator and then lecturer in physiology in Prof. Hemingway's department in Leeds. $\mathrm{He}_{\theta}$ was appointed senior lecturer in physiology in Prof. Samson Wright's department at the Middlesex Hospital Medical School in 1950, and became reader in 1953. Prof. Neil's research activities have been varied, but his most important contributions have related to blood gases, reflex control of the circulation, studies on the larynx and the physiological changes accompanying hypothermia. His early academic interest in oxygen and carbon dioxide dissociation curves in blood found an important practical application when he came to study the disturbances induced by hypothermia in cardiac surgery. He was the first to describe the severe metabolic acidæmia and the serious liver damage which may accompany this procedure. He has made many important contributions to the reflex control of the circulation and respiration using electrophysiological techniques to study the activities of baro- and chemo-receptors. Some of this work was done in conjunction with Prof. Y. Zotterman in Stockholm. Prof. Neil is at present writing a monograph with Prof. C. Heymans, of Ghent, on this subject.

\section{Tribute to Prof. M. Saha}

THE issue of Science and Culture for October 1956 is a special number devoted to the late Prof. Meghnad Saha's activities in research, education and scientific organization. The issue contains ten articles by colleagues, friends and students of Prof. Saha, dealing with his contributions to astrophysics, nuclear physics and the development of atomic research in India, geophysics, calendar reform, river valley developments, and his success as a teacher and organizer. Prof. Saha's contribution to the Dr. D. M. Bose Seventieth Birthday Commemoration Volume of the Transactions of the Bose Research Institute (20, 109 ; 1955) was an account of the present position of nuclear reactor development, and it is fitting that in the special number Dr. Bose should pay tribute to Saha by an article suggesting how the atomic energy power programme in India should proceed. He maintains that of the many proposals now being discussed concerning the most suitable form of memorial to commemorate the outstanding services of the late Prof. Saha, nothing could be better than the erection of a nuclear reactor in the region served by the Institute of Nuclear Physics, Calcutta, the existence and present development of which are almost solely due to his efforts. Besides being an academic scientist who achieved international distinction by his theory of thermal ionization in solar and stellar atmospheres, Prof. Saha was responsible for a large number of extra-mural activities. He took the initiative in founding the National Academy of Sciences in India and became its first president in 1932 , and in 1935 Prof. Saha became the first joint secretary of the National Institute of Sciences of 